\title{
Comparison between different water-treatment works in El-Menofeyia province, Egypt
}

\author{
Mansour Galal $^{1}$, E. Khallaf ${ }^{1}$, A. El-Naenae ${ }^{1}$ and A. Mousa ${ }^{2}$ \\ 1 - Fac. of Science, Menofeyia Univ., Shebin El-Koum. \\ 2 - General Org. of Water-treatment authority of Shebin El-Koum.
}

\begin{abstract}
This study was carried out during a period extending between March 2016 and February 2017. The aim of this work is to make a comparison between certain physicochemical and biological parameters at three different water plants in El-Menofeyia province, Egypt. According to data of the physico-chemical parameters, the treated water at these treatment plants proved a remarkable enhancement as compared with raw one mainly with the values of TDS, Conductivity, Turbidity, Total alkalinity, Phosphates, Nitrates and Ammonia. Regarding biotic component, it was proved that both Total and Fecal coliform beside protozoans disappeared more or less completely at the end of the water treatment process in the present study. On the other hand, the protozoan organisms showed that the total protozons, sarcodines and ciliates' numerical densities achieved the highest densities during June 2016 in Meligue and Dalaton influent water, while those of Shobra-bass occurred on March for ciliates, October-November for flagellates and August for sarcodines. From the practical and statistical point of views, it could be possible to conclude that the direct filtration treatment process (Meligue) was the most effective method to obtain better potable water followed by the river-bank filtration (Dalaton) then the compact water treatment plant at Shobra-bass.
\end{abstract}

Key words : Water-treatment plants, physico-chemical parameters, protozoa, total and fecal coliform bacteria, El-Menofeyia province, Egypt.

\section{INTRODUCTION}

River Nile is considered as the main Egyptian water sources for the domestic, industrial and irrigation uses. The rapid increase in population and urbanization is a big challenge to the country in facing water scarcity (El Gammal, 2008). One of the most important factors of water pollution is the microbial contaminations; especially with pathogenic microorganisms. Pathogens are typically responsible for waterborne diseases (Karaboze et al., 2003). Bacteriological water analysis is a method of analyzing water to estimate the numbers of bacteria present and find the sort of bacteria that contaminated the water source (Sabae and Rabeh, 2007). Twenty percent of the world's population lacks safe drinking water, and nearly half the world population lacks adequate sanitation. In addition, water contamination also leads to the increase in parameters like biological oxygen demand (BOD), chemical oxygen demand (COD), total dissolved solids (TDS), total suspended solids (TSS), and salinity and thus deteriorates the water quality and make it unfit for drinking and other purposes. Consequently, potable water should be colorless, tasteless, odorless and free from any micro-organisms. This processes involves removing the contaminants using physical processes such as settling and filtration, chemical processes such as disinfection and coagulation and biological processes such as rapid and slow sand filtration (Galal, 1989).

Measuring of certain physico-chemical parameters of water is very important to investigate both water quality and ecological variations of the water body (WHO, 1996). Chlorine is widely used as a disinfectant at water treatment plants, but its concentrations did not kill some protozoan organisms and their cysts (Wallis et al., 1996; Liberti et al., 2002). 


\section{Mansour Galal et al.}

Conventional water treatment plant has a series of treatment processes such as coagulation, flocculation and clarification through sedimentation, filtration and disinfection. Direct filtration is considered as a conventional plant without clarifiers.

Compact water treatment plant is a type of treatment which is carried out through coagulation (via coagulant alum), filtration in a closed container with sandy media in the ground of the filter and disinfection through chlorine.

River Bank Filtration is the infiltration of surface water, mostly from a river system into a groundwater system induced by water abstraction close to the surface water as a river bank. As the water flows through the soil, it is filtered and its quality hence is improved (Sharma and Amy, 2009; Huelshoff et al., 2009). Bank Filtration has been used for over 100 years in Europe and is now gaining interest and application globally as an effective process for reducing organic and particulate loads to drinking water treatment systems (Schmidt et al., 2003).

The microbiological quality of water and the effectiveness of treatment are based on fecal contamination indicators. Ciliated protozoans, together with bacteria, algae colorless flagellates, small metazoans such as rotifers, crustaceans and nematodes, constitute the characteristic plankton community of freshwater ecosystems and play an important role in its trophic structure (APHA; 1992 and Sola et al.; 1996). Also, ciliates play a significant role in decomposition process and nutrient recycling (Madoni and Zangrossi, 2005; Senler and Yildiz, 2004). Changes in species diversity and structure are a reliable and generally useful means for assessing the biological effects of pollution (Velho et al., 2005; Madoni and Zangrossi, 2005; Chen et al., 2008). The tolerance of ciliates to ammonia is necessary in the toxicological studies of aquatic ecosystems (Xu et al., 2004).

In water treatment plants, it is generally accepted that the feeding of ciliates on bacteria improve the treatment process, resulting in a lower organic load in the output water. Due to their biodegradation potential some attempts have been made to use ciliates specifically in environmental biotechnology (Pauli et al., 2001; Spellman; 2003). Therefore, this study aims to compare between certain physico-chemical and biological parameters at three different water plants in El-Menofeyia province, Egypt. These plants apply different water treatment methods as mentioned previously.

\section{MATERIALS AND METHODS}

Water samples were collected using sterilized one liter polypropylene containers at 30 $\mathrm{cm}$ below water surface from inlets of three different water treatment plants; Meligue, Shobra-bass and El- Dalaton. The former plant is a direct filtration water treatment plant; the second one is a compact water t plant, while the latter one is a well that located next to the River Nile (Bank Filtration). Water samples were collected during a period extending from March 2016 to February 2017 and were analyzed physico-chemically using APHA (2005) method.

Total coliform $(\mathrm{Tc})$ and fecal coliform $(\mathrm{Fc})$ bacteria were used as indicators for pollution in all water samples. Total and fecal coliform bacteria were investigated and counted using membrane filter technique method according to APHA (1998) and EPA (2005).

Protozoan sedimentation was carried out as mentioned by Galal et al. (2008), while their identification was performed using Patterson and Hedley (1996) in laboratories of Zoo. Dept., Faculty of Science, El-Menofeyia University. Statistical analyses were performed using Minitab statistical package. 


\section{Comparison between different water-treatment works in El-Menofeyia province, Egypt}

\section{RESULTS}

According to the present physico-chemical data of the three examined water-treatment plants, it appears that the treated water (effluent) of these water works exhibited a remarkable enhancement as compared with the raw one (influent) mainly in TDS, Conductivity, Turbidity, temperature, total alkalinity, phosphates, nitrates and ammonia. The latter three parameters beside the turbidity showed the highest efficiencies at Meligue effluent water as compared to those of the other two plants. Simultaneously, it was proved that most of the physico-chemical parameters of Meligue treated water have more satisfied values than those of Dalaton and Shobra-bass water-treatments' plants, respectively. Regarding the treated water, it was found that TDS, conductivity, total alkalinity, total hardness, turbidity, iron, manganese, phosphates, nitrates and ammonia of Shobra-bass were mostly higher in their values as compared with those of the other two water plants particularly during spring as could be seen in Figures (1 and 2). Taking Coliform bacteria (Total and Fecal types) in our consideration, it was proved that the influent water samples of these water works have varying contamination levels (22700 TC $-10600 \mathrm{FC} / 100 \mathrm{ml}$ monthly). The highest densities of these bacteria were recorded during August 2016 and the lowest ones occurred on February 2017. The highest numbers of Total Coliform were detected at Shobra-bass followed by those of Meligue and then those belonging to El-Dalaton plants, while those of Fecal Coliform illustrated maximal densities at Meligue, then Shobrabass followed by ElDalaton (Table (2). The treated water (effluent) illustrated completely nill for both types of bacteria $(<1 / 100 \mathrm{ml})$ apart from very few total coliform values at Shobra-bass compact watertreatment work.

Data of the protozoan organisms indicated the presence of two genera of sarcodines, seven mastigophoreans and 13 of ciliates at Meligue influent (raw) water, while those of Shobra-bass and Dalaton achieved 2, 13, 27 and 2,13 and 16 genera, respectively as could be seen in Table (1). The total protozoan organisms at Shobrabass influent water showed higher numerical densities than those of Meligue and Dalaton plants. On the other hand, influent total protozoa of Dalaton water plant exceeds those of Meligue during a period extending only from March to September 2016, while those in-between November and January behaved in an opposite manner. It is worthy to mention that ciliates showed the highest numerical densities followed by flagellates and then sarcodines. The maximal and minimal monthly numerical densities varied between 69 and $2910^{3} / \mathrm{L}$ during June and January, respectively at Meligue influent water, 183 and $5210^{3} / \mathrm{L}$ on March and January at Shobra-bass, 84 and 11 on June and January at El-Dalaton. Considering flagellates, their respective values were 33 and 2 on August and Novmber, 33 and 20 on October and February and 43 and $910^{3} / \mathrm{L}$ during March and February at Meligue, Shobra-bass and El-Dalaton, respectively. Regarding sarcodines, the upper and the lower numerical densities were 4 and 1 ; 5 and $1 ; 3$ and $010^{3} / \mathrm{L}$ at Meligue, Shobra-bass and El- Dalaton inflow water, respectively.

\section{DISCUSSION}

It is obvious in the present study that some of the parameters showed high values in municipal pipes and distribution system which could be referred to damage, leakage and rusting of its pipes. Temperature is considered as a very significant factor influencing various activities of the microorganisms (Galal et al., 2011; Gopalkrushna, 2011). It has a positive significant correlation with turbidity in both conventional and direct filtration water plants (Galal, et al.; 2014). Turbidity is one of the daily monitoring parameters in water treatment that affects other water characters such as health, physical and disinfection aspects (Mazloomi et al.,2009). It is the most widely used particle measurements in water treatment process that include coagulation, sedimentation and filtration (WHO, 2009).Hydrogen ion concentration is considered as a controlling factor affecting dissolved oxygen and total 


\section{Mansour Galal et al.}

alkalinity. Its values in the present study ranged between 7.6-7.9 at the different stages of these water plants and the highest levels were recorded during summer and winter which is parallel to those of Elawa and Mahdi (1988).

The present data illustrated higher $\mathrm{pH}$ values on summer as compared to those of winter and other seasons which could be referred to the decomposition of the organic matter which is confirmed with the findings of Birhanu (2007). The total dissolved salts (TDS) achieved the maximum values on winter in all water samples of the water treatment plants which is in agreement with those of Elawa and Mahdi (1988) and opposite to those of Elewa and Authman (1991). Simultaneously, TDS values showed high positive correlation with the electrical conductivity which is confirmed with data obtained by Galal et al. (2014). Decreasing of conductivity may be attributed to the precipitation of calcium carbonate which is mainly caused by algal depletion and secondarily by higher temperatures.

According to the present data, it was proved that total alkalinity (carbonate and bicarbonate), total hardness (Calcium and Magnesium) which affects toxicity of the pollutants and chloride ions (sewage pollution indicator) achieved their highest levels mostly during winter and autumn, while the lowest ones were obtained mainly on summer and spring exactly as those obtained by Helal, (1981), Elewa and Authman, (1991) and Bergmann, (2009).

The seasonal levels of iron concentrations in the present investigation did not exceed $0.07 \mathrm{mg} / \mathrm{L}$ which is parallel to those of Galal (2014). The presence of iron and manganese at different water treatment stages and at the drinking water distributing system could be referred to the using of ferric coagulants as well as using steel pipes which is confirmed by Thompson et al. (2009).

Ammonia in water samples of the present study is an indicator of bacterial, sewage and animal waste pollution. Ammonia is occasionally found in potable water samples and distribution system (less than $0.4 \mathrm{mg} / \mathrm{L}$ ) where chlorine is used as a residual disinfectant (WHO, 2009) keeping in mind that Shobra-bass water treatment plant has no clarification. It was found that the seasonal values of ammonia showed a minimum concentration on spring and a maximum level during summer in both Meligue and Dalaton water plants, while those of Shobra-bass were achieved on winter and autumn, respectively.

Nitrates can reach both surface and ground water as a consequence of agricultural activity and also from waste water disposal product from human. The seasonal nitrate concentrations of the present study exceeded the international permissible limits. This could be due to variations in pollution levels in the municipal pipes of water treatment plant and the connected pipes for consumers.

Phosphates are very important elements for phytoplankton growth. It stimulates the activity of nitrogen fixing bacteria and increasing the nitrifying activity of the soil (Authman, 1991). The present phosphate levels exceed those of the Environmental Protection Agency limits $(0.1 \mathrm{mg})$ which could be an indication of sewage contamination which is a serious environmental problem as it adversely affects the human health and the biodiversity in the aquatic ecosystem (APHA, 2005). Drinking water must meet specific criteria to ensure that water supply to the public is safe and free from any pathogenic microorganisms as well as hazardous compounds (WHO, 2009).

The total and fecal coliforms were not detected in treated, filtrated and potable water samples which could be attributed to the effectiveness of the disinfection process which is concomitant with pathogenic bacteria (WHO, 1993). Raw water of the present study was contaminated with fecal material of different origin. The positive results of coliform bacteria in treated water of certain stages in treatment plants might indicate the presence of bio-film in the distribution system. Protozoan organisms were detected throughout the year mainly at the three water treatment plants with highest densities among other plankton and they were 


\section{Comparison between different water-treatment works in El-Menofeyia province, Egypt}

mostly absent from filtered and treated water which could be attributed to the effect of adding chlorine and coagulant alum mainly at Meligue and Shubra-bass water plants.

In aquatic environments, ciliates are considered as mediators of energy transfer from pico- and nano-plankton levels to higher trophic ones in the functioning microbial loop (Dolan and Coats, 1990; Sime-Ngando et al., 1995; Jiang et al., 2013). It is becoming increasingly recognized that there are several advantages in using ciliated protozoan for the assessment of water quality due to their short life cycles, their semipermeable membranes and their reacting more rapidly to the environmental changes than other eukaryotic organisms. Furthermore, many forms can inhabit environments that are unsuitable to metazoan organisms (Cairns et al., 1972; Franco et al., 1998; Corliss 2002; Madoni and Braghiroli, 2007; Jiang et al., 2007). Other investigations have revealed that some dominant species are significantly correlated with concentrations of nutrients (Jiang et al., 2011). Thus, it is possible to conclude that some ciliates could respond predictably to different environmental conditions.

The relations between biotic and abiotic components could be examined via simple and multiple regression analyses by applying Minitab statistical package and the significant relationships could be seen in Table (3). By applying stepwise regression analysis, it was proved that Meligue water plant was the most efficient one in producing potable water followed by El-Dalaton and then Shobra-bass plant.

\section{REFERENCES}

American Public Health Association (APHA), (1992). Standard methods for examination of water and wastewater. Washington, DC, $268 \mathrm{pp}$.

American Public Health Association (APHA), (1998). Standard methods for the examination of water and wastewater. $20^{\text {th }}$ ed., Washington, DC.

American Public Health Association (APHA) (2005): Standard methods for the examination of water and wastewater, $21^{\text {th }}$ ed., American Public HealthAssociation Inc., New York.

Authman, M.(1991). Studies on some biological aspects of Bagrus bayad (Family: Bagridae) from Bahr Shebeen Canal. MSc. Thesis, Zool. Dep., Fac. Sci., Minofeya University, Egypt.

Bergmann, E. (2009). Techniques for water analysis. Secondary- Tertiary Interface, The Royal Australian Chemical Institute Inc, Qld Branch Chemical Education Group.

Birhanu, M. (2007). Assessment of Physico-chemical and microbiological quality of drinking water at sources and house hold in selected communities of Akaki-Kaliti sub city, Addis Ababa City Administration. M.Sc., Thesis Addis Ababa University, School of Graduate Studies.

Cairns, J.Jt.; G.R. Lanza and B.C. Parker (1972). Pollution related to structural and functional changes in aquatic communities with emphasis on freshwater algae and protozoa. Proc. Acad. Nat. Sci. Philad., 124: 79 - 127.

Chen, Q.H.; Xu R.L.; Tam, N.F.; Cheung, S.G. and Shin, P.K. (2008). Use of ciliates (Protozoa: Ciliophora) as bioindicator to assess sediment quality of two constructed mangrove sewage treatment belts in Southern China. Mar. Pollut. Bull., 57 (612), 689-694.

Corliss, J.O. (2002). Biodiversity and biocomplexity of the protists and an overview of their significant roles in maintenance of our biosphere. Acta Protozool., 41:199-219.

Dolan, J.R. and D.W. Coats (1990). Seasonal abundance of planktonic ciliates and microflagellates in mesohaline Chesapeake Bay waters. Estuar. Coast Shelf Sci., 31: $157-175$.

Elewa, A. and Authman, M. (1991). Limnological studies on Bahr Shebeen El kom Canal, Menoufiya Governorate, Egypt. Fac. Sci., Zagazig University, Egypt. 


\section{Mansour Galal et al.}

Elewa, A. A. and Mahdi, H. (1988). Some Limnological studies on the Nile water at Cairo, Egypt. Bull. Inst. Oceanogr., Fish., A.R.E., 14:141- 152.

El-Gammal, H., (2008.: Data Collection for design of water and wastewater treatment facilities, Report No.43, Environmental Services for Improving Water Quality management in Egypt.

Environmental Protection Agency, EPA (2005). Methods of microbiological analysis of drinking water and waste water. Method, 441.2. New Hampshire Department of Environmental Services (NHDES) (Interpreting VRAP Water Quality Monitoring Parameter. http://des.nh.gov/organization/divisions/water/wmb/vrap/index.htm.

Franco, C.; Esteban, G. and Téllez, C. (1998). Colonization and succession of ciliated protozoa associated with submerged leaves in a river. Limnologica, 28:275-283.

Galal, M. (1989). Ecological studies on the ciliate and bacterial populations of slow sand filters. Ph.D Thesis, London University.

Galal, M.; Authman, M.N. and Gaber , N. (2008). Ciliated Protozoan diversity in Rosetta branch in El-Menofeyia province. Afr. J.Biol.Sci., 4(2):35-45.

Galal, M.; Authman, M.N. and Gaber, N. (2011). Ciliated protozoan diversity at El-Hammra hypersaline lake, Wadi Al-Natron Egypt. Afr. J.Biol.Sci.,7 (2): 1-12.

Galal, M.; Osman, G.Y.; Mohamed, A.H. and Aboamer, M. (2014). Evaluation of the relationships of certain ecological parameters and prevalence of Giardia and Entamoeba cysts at two water treatment plants, at El- Menoufia Province, Egypt. J. Egypt. Acad. Soc. Environ. Develop., (D- Environmental Studies), 16(1): 1-11.

Galal, M.; khallaf, E.A.; Elsbbagh, S. and Nabet, N.M. (2014). A study of the physicochemical and biological characteristic of raw water, filtrated and treated water at a water treatment plant in Shebin Elkom, Menoufiya, Egypt. J. Egypt. Acad. Soc. Envir. Dev., (D- Environmental Studies), 15:160-170 .

Gopalkrushna, H.M. (2011).Determination of Physicochemical parameters of surface water samples in and around Akot City. Inter. J. Res. in Chem. and Environ.,1:183-187.

Helal, H.A. (1981). Studies on the zooplankton of Damietta Branch of the River Nile North of El-Mansoura. MSc. Thesis, Fac. Sci., El-Mansoura Univ., 231 pp.

Huelshoff, I.; Greskowiak, J.; Gruetsmacher, G. (2009). Analysis of the vulnerability of bank filtration systems to climate change by comparing their effectiveness under varying environmental conditions. URL [Accessed: 29.08.2011].

Jiang, J.; Wu, S. and Shen, Y (2007). Effects of seasonal succession and water pollution on the protozoan community structure in an eutrophic lake. Chemosphere, 66:523-532.

Jiang, Y.; Xu, H.; Hu, X.; Zhu, M.; Al-Rasheid, K.A.S. et al. ( 2011). An approach to analyzing spatial patterns of planktonic ciliate communities for monitoring water quality in Jiaozhou Bay, northern China. Mar. Pollut. Bull., 62 (2): 227-235.

Jiang, Y.; Xu, H.; Hu, X.; Warren, A. and Song, W. (2013). Functional groups marine ciliated protozoa and their relationships to water quality. Environ. Sci. and Pollut. Res., 20 (8): 5272-5280.

Karaboze, I.; Ucar , F.; Eltem, R.; Ozdmir, G. and Ates, M. (2003). Determination of existence and count of pathogenic microorganisms in Izmir Bay. J.E.S 26:1-18.

Liberti, L.; Notarnicola, M. and Petruzzelli, D. (2002). Advanced treatment of municipal wastewater reuse in agriculture. UV disinfection: parasite removal and by-product formation. Desalination, 152: 315-324.

Madoni, P. and Braghiroli, S. (2007). Changes in the cilia blage along a fluvial system related to physical and geomorphological characteristics. European Journal of Protistology: 43 (2): $67-75$.

Madoni, P. and Zangrossi, S. (2005). Ciliated protozoa and saprobical evaluation of water quality in the Taro River (northern Italy). Ita. J. Zool., 72: 21-25. 


\section{Comparison between different water-treatment works in El-Menofeyia province, Egypt}

Mazloomi, S.; Dehghani, M.H.; Norouzi, M.; Davil, M.F.; Amarluie, A.; Tardast, A. and Karamitaba, Y.(2009). Physical and chemical water quality of Ilam water treatment plant. World Appl. Sci. J., 6 (12): 1660-1664.

Patterson, D.J. and Hedley, S. (1996). Free-Living Freshwater Protozoa: A colour guide. Wolf Publishing Ltd., London, England.

Pauli, W.; Jax, K. and Berger,S. (2001). Protozoa in wastewater water treatment: Function and Importance. The Handbook of Environmental Chemistry. Vol. 2k. 203-252.

Sabae, S.Z. and Rabeh , S.A. (2007). Evaluation of the microbial quality of the River Nile water at Damietta branch , Egypt. Egypt. J. Aquat. Res., 33: 301-311.

Schmidt , C.K.; Lange, F.T.; Brauch , H.J.; Kuehn, W. (2003). Experiences with Riverbank Filtration and Infiltration in Germany. Karlsruhe: DVGW-Water Technology Center (TSW). URL [Accessed: 15.05.2013].

Senler, N.G. and Yildiz, Ü. (2004). Faunistic and morphological studies on ciliates (protozoa, Ciliophora) from a small pond, with responses of ciliate populations to changing environmental conditions. Turk. J. Zool., 28:245-265.

Sharma, S.K. and Amy, G. (2009): Bank Filtration - A Sustainable Water Treatment Technology for Developing Countries. (= 24th WEDC International Conference, Addis Ababa, Ethiopia). Delft: UNESCO-IHE. URL [Accessed: 24.08.2011].

Sime-Ngando T, Gosselin M, Roy S, Chanut JP (1995) Significance of planktonic ciliated protozoa in the lower St. Lawrence estuary: comparison with bacterial, phytoplankton, and particulate organic carbon. Aquat Microb Ecol 9:243-258.

SOLA, A., LONGÁS, JF., SERRANO, S. and ALMUDENA, A. (1996). Influence of environmental characteristics on the distribution of ciliates in the River Henares (Central Spain). Hydrobiologia, vol. 324, p. 237-252.

Spellman, F.R. (2003). Handbook of Water and Wastewater Treatment Plant Operations. First ed., CRC Press.

Thompson, T., Faweel, J., Kunikane, S., Darryl Jackson, Appleyard,S., Callan, P.; Jamie Bartram, J. and Kingston, P. (2009): Chemical safety of drinking water: Assessing priorities for risk management. J. Appl. Microbiol. 255- 271.

Velho, L.F.M., Pereira, D.G., Pagioro, T.A., Santos, V.D., Perenha, M.C.Z. et al., (2005). Abundance, biomass and size structure of planktonic ciliates in reservoirs with distinct trophic states. Acta Limnologica Brasiliensis, 17 (4), 361-371.

Wallis, P.M., Erlandsen, S.L., Isaac-Renton, J.L., Olson, M.E., Robertson, W.J. and van Keulen, H. (1996) :Prevalence of Giardia cysts and Cryptosporidium oocysts \& characterization of Giardia species isolated from drinking water in canada. Appl .Environ. Microbiol. 62, 2789-2797.

World Health Organization (WHO) (1993). Guidelines for drinking water quality. $2^{\text {nd }}$ ed , Vol.1, Geneva Switzerland: Office of Publication.

World Health Organization (1996). Guidelines for Drinking-water quality, Vol. 2, 2nd ed., Geneva.

World Health Organization (WHO) (2009). Guidelines for Drinking Water Quality incorporating the first and second addenda,Vols. 1 \& 3. Geneva.

Xu, H.; Song, Lu. L. and Warren, A. (2004). Tolerance of ciliated protozoan Paramecium bursaria (Protozoa, Ciliophora) to ammonia and nitrites. J. Chinese. Oceanol. Limnol., 23: 349-353. 
Mansour Galal et al.

Table (1). Protozoan genera at three different water-treatment works in ElMenoufeyia Province.

\begin{tabular}{|c|c|c|c|c|c|}
\hline Table (1). & Meligue & \multicolumn{2}{|l|}{ Shubrabass } & \multicolumn{2}{|l|}{ Dalaton } \\
\hline Sarcodina & $\begin{array}{l}\text { Nuclearia } \\
\text { Arcella }\end{array}$ & \multicolumn{2}{|l|}{$\begin{array}{l}\text { Amoeba } \\
\text { Arcella }\end{array}$} & \multicolumn{2}{|l|}{$\begin{array}{l}\text { Amoeba } \\
\text { Arcella }\end{array}$} \\
\hline Mastigophora & $\begin{array}{l}\text { Euglena } \\
\text { Cryptomonas } \\
\text { Peranema } \\
\text { Peridinium } \\
\text { Ceratium } \\
\text { Astasia } \\
\text { Chlorogonium }\end{array}$ & $\begin{array}{l}\text { Peridinium } \\
\text { Peranema } \\
\text { Euglena } \\
\text { Cryptomonas } \\
\text { Ceratium } \\
\text { Synura } \\
\text { Heteronema } \\
\text { Eudorina }\end{array}$ & $\begin{array}{l}\text { Carteria } \\
\text { Actionmonas } \\
\text { Chlorogonium } \\
\text { Uroglena } \\
\text { Trachelius }\end{array}$ & $\begin{array}{l}\text { Eudorina } \\
\text { Heteronema } \\
\text { Uroglena } \\
\text { Carteria } \\
\text { Actionmonas } \\
\text { Euglena }\end{array}$ & $\begin{array}{l}\text { Chlorogonium } \\
\text { Cryptomonas } \\
\text { Uroglena } \\
\text { Peranema } \\
\text { Ceratium } \\
\text { Actionmonas } \\
\text { Synura }\end{array}$ \\
\hline Ciliophora & $\begin{array}{l}\text { Halteria } \\
\text { Aspidisca } \\
\text { Colpoda } \\
\text { Euplotes } \\
\text { Tetrahymena } \\
\text { Paramecium } \\
\text { Tachysoma } \\
\text { Cyclidium } \\
\text { Childonella } \\
\text { Colpidium } \\
\text { Vorticella } \\
\text { Anisonema } \\
\text { Centophyxis }\end{array}$ & $\begin{array}{l}\text { Colpidium } \\
\text { Acineta } \\
\text { Colpoda } \\
\text { Homalozoon } \\
\text { Climacostmum } \\
\text { Stentor } \\
\text { Vorticella } \\
\text { Lacrymaria } \\
\text { Chlamydodon } \\
\text { Glaucoma } \\
\text { Cyclidium } \\
\text { Strobilidium } \\
\text { Tachysom }\end{array}$ & $\begin{array}{l}\text { Frontonia } \\
\text { Acanthocystis } \\
\text { Coleps } \\
\text { Tetrahymen } \\
\text { Chilodenlla } \\
\text { Euplotes } \\
\text { Aspidisca } \\
\text { Dileptus } \\
\text { Halteria } \\
\text { Phascolodon } \\
\text { Podophyra } \\
\text { Tpkokphyra } \\
\text { Paramecium } \\
\text { Nassula }\end{array}$ & $\begin{array}{l}\text { Litonous } \\
\text { Halteria } \\
\text { Podophyra } \\
\text { Aspidisca } \\
\text { Nassula } \\
\text { Tetrahymena } \\
\text { Vorticella } \\
\text { Tokophyra }\end{array}$ & $\begin{array}{l}\text { Homalozoon } \\
\text { Colpidium } \\
\text { Paramecium } \\
\text { Coleps } \\
\text { Stentor } \\
\text { Strobilidium } \\
\text { Dileptus } \\
\text { Glaucoma }\end{array}$ \\
\hline Total Protozoa & 22 & \multicolumn{2}{|l|}{42} & \multicolumn{2}{|l|}{31} \\
\hline
\end{tabular}

Table (2). Monthly numerical densities of Total (T) and Fecal (F) Coliforms /100 ml at Different water treatment works in El-Menofeyia Province, Egypt.

\begin{tabular}{|l|c|c|c|c|c|c|c|c|c|c|c|c|}
\hline \multicolumn{1}{|c|}{ Month } & \multicolumn{4}{|c|}{ Dalaton } & \multicolumn{3}{c|}{ Shobrabass } & \multicolumn{4}{c|}{ Meligue } \\
\hline & \multicolumn{2}{|c|}{ Raw } & Treated & \multicolumn{2}{c|}{ Raw } & \multicolumn{2}{c|}{ Treat } & \multicolumn{3}{c|}{ Raw } & \multicolumn{3}{c|}{ Treat } \\
\hline & T & F & T & F & T & F & T & F & T & F & T & F \\
\hline March $_{2016}$ & 16500 & 6500 & $<1$ & $<1$ & 18200 & 7100 & 17 & $<1$ & 18800 & 8400 & $<1$ & $<1$ \\
\hline April & 17700 & 7000 & $<1$ & $<1$ & 18700 & 7400 & $<1$ & $<1$ & 15700 & 8100 & $<1$ & $<1$ \\
\hline May & 16500 & 5500 & $<1$ & $<1$ & 15100 & 6300 & 14 & $<1$ & 12200 & 7300 & $<1$ & $<1$ \\
\hline June & 20000 & 8900 & $<1$ & $<1$ & 16100 & 7100 & 22 & $<1$ & 16700 & 8100 & 14 & $<1$ \\
\hline July & 16500 & 6600 & $<1$ & $<1$ & 19800 & 8700 & $<1$ & $<1$ & 20400 & 9700 & $<1$ & $<1$ \\
\hline Aug. & 22500 & 9000 & $<1$ & $<1$ & 22700 & 9600 & $<1$ & $<1$ & 23200 & 10600 & $<1$ & $<1$ \\
\hline Sept. & 11200 & 4000 & $<1$ & $<1$ & 11700 & 4400 & $<1$ & $<1$ & 12300 & 5400 & $<1$ & $<1$ \\
\hline Octb. & 11200 & 3800 & $<1$ & $<1$ & 12500 & 5300 & 15 & $<1$ & 13300 & 6300 & $<1$ & $<1$ \\
\hline Nov. & 10000 & 3500 & $<1$ & $<1$ & 13200 & 5700 & $<1$ & $<1$ & 14100 & 6700 & $<1$ & $<1$ \\
\hline Dec. & 8800 & 4600 & $<1$ & $<1$ & 11500 & 5600 & $<1$ & $<1$ & 12200 & 6600 & $<1$ & $<1$ \\
\hline Jan 2017 & 8000 & 2000 & $<1$ & $<1$ & 9600 & 3300 & 8 & $<1$ & 10600 & 4300 & $<1$ & $<1$ \\
\hline Feb.2017 & 8800 & 1000 & $<1$ & $<1$ & 8500 & 1200 & $<1$ & $<1$ & 9500 & 2200 & $<1$ & $<1$ \\
\hline
\end{tabular}


Comparison between different water-treatment works in El-Menofeyia province, Egypt

Table (3). Summary of the statistically significant relationships of biotic and abiotic parameters in three water treatment works in El-Menofeyia Province.

\begin{tabular}{|c|c|c|c|c|c|}
\hline W.T. Plants & Parameter & B & df & $\mathbf{F}$ & $\mathbf{P}$ \\
\hline \multirow[t]{8}{*}{ Meligue } & T. Protz Vs Cond & -0.21 & 1,25 & 7.38 & 0.012 \\
\hline & Vs Temp & 3.49 & 1,25 & 4.87 & 0.037 \\
\hline & Vs Chlorine & -2.55 & 1,25 & 4.01 & 0.053 \\
\hline & Vs Rotifers & 4.54 & 1,25 & 7.28 & 0.013 \\
\hline & Vs T.Coliform & 2.62 & 1,25 & 4.92 & 0.036 \\
\hline & T. Coliform Vs Temp. & 0.81 & 1,25 & 14.34 & 0.001 \\
\hline & T. Coliform $\mathrm{Vs} \mathrm{Cl}$ & -0.51 & 1,25 & 7.36 & 0.021 \\
\hline & T. Coliform Vs Temp. \& Cl & $\begin{array}{ll}b_{1=0.67} & b_{2=-0.31} \\
\end{array}$ & 2,25 & 9.39 & 0.001 \\
\hline \multirow[t]{12}{*}{ Shobrabass } & T. protz. Vs Cond. & -0.12 & 1,23 & 4.26 & 0.050 \\
\hline & Vs Temp & 4.13 & 1,23 & 8.12 & 0.009 \\
\hline & Vs Cond \& Temp & $\mathrm{b} 1=-0.06 \quad \mathrm{~b} 2=3.37$ & 2,23 & 4.56 & 0.023 \\
\hline & Vs T.Colif & 3.39 & 1,25 & 12.69 & 0.002 \\
\hline & Vs F.Colif & 4.59 & 1,25 & 5.32 & 0.030 \\
\hline & Vs T \& F. Colf & $b_{1}=6.17 \quad b_{2}=-5.77$ & 2,25 & 7.69 & 0.003 \\
\hline & T.Colf Vs TDS,Temp\& TA & $\begin{array}{l}b 1=-0.11 \quad b 2=0.02 \\
b 3=-0.12\end{array}$ & 3,25 & 3.04 & 0.050 \\
\hline & T.Colf $\mathrm{Vs} \mathrm{Cl}$ & -0.5 & 1,25 & 14.99 & 0.001 \\
\hline & \begin{tabular}{|ll} 
F.Colf & Vs TDS \\
\end{tabular} & -0.02 & 1,25 & 4.21 & 0.05 \\
\hline & F.Colf Vs Cond. & -0.012 & 1,25 & 6.5 & 0.018 \\
\hline & F.ColfVs Temp. & 0.38 & 1,25 & 9.75 & 0.003 \\
\hline & F.Colf Vs TDS, Cond \& TA & $\begin{array}{ll}b 1=-0.07 & b 2=0.02 \\
b 3 & =-0.07\end{array}$ & 3,25 & 5.56 & 0.005 \\
\hline \multirow[t]{13}{*}{ El-Dalaton } & $\begin{array}{ll}\text { T.protz . } & \text { Vs Temp } \\
\end{array}$ & 4.38 & 1,25 & 8.73 & 0.007 \\
\hline & Vs T. Alkl & -0.79 & 1,25 & 7.77 & 0.01 \\
\hline & Vs Temp \&T.Alkal & $\mathrm{b} 1=3.48 \quad \mathrm{~b} 2=-0.6$ & 2,25 & 7.66 & 0.003 \\
\hline & Vs T.Colif & 3.39 & 1,25 & 12.69 & 0.002 \\
\hline & Vs F.Colif & 4.59 & 1,25 & 5.32 & 0.030 \\
\hline & Vs T.\&F.Colif & $\mathrm{b} 1=6.17 \quad \mathrm{~b} 2=-5.8$ & 2,25 & 7.69 & 0.003 \\
\hline & $\begin{array}{ll}\text { Tc Vs TDS, Cond, Cl, Temp,Tur, } \\
\text { T.Alk, T.H . } \\
\end{array}$ & & 7,25 & 6.53 & 0.001 \\
\hline & Vs Temp, T.Alk, Cl, T.protz & & 4,25 & 10.01 & $<0.001$ \\
\hline & F.Colf Vs Temp & 0.47 & 1,25 & 13.37 & 0.001 \\
\hline & Vs T.Alk & -0.59 & 1,25 & 4.54 & 0.044 \\
\hline & F.Colf $\mathrm{Vs} \mathrm{Cl}$ & -0.22 & 1,25 & 8.78 & 0.007 \\
\hline & F.Colf Vs Temp, T.Alk,Cl & & 3,25 & 10.18 & $<0.001$ \\
\hline & F.Colf Vs Temp, T.Alk, Cl \&T.Protz & & 4,25 & 10.01 & $<0.001$ \\
\hline
\end{tabular}




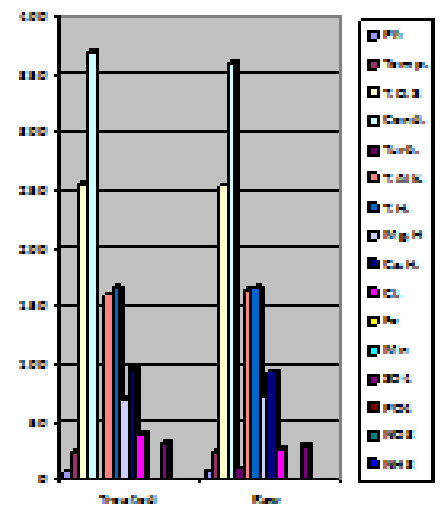

El-Dalaton WTW

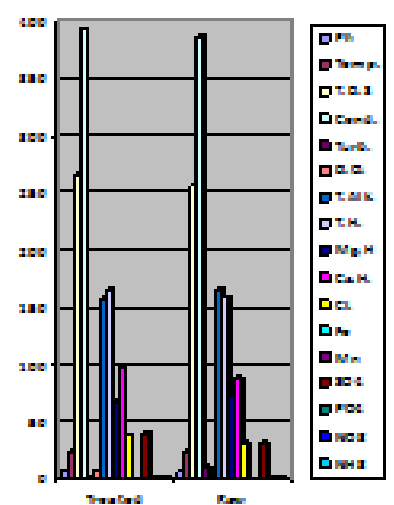

Shobra-bass WTW

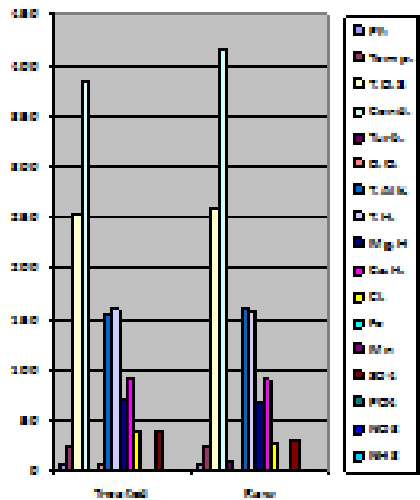

Meligue WTW

Figure (1) Physico-chemical parameters of Raw and Treated water at three different water treatment works in El-Menofeyia Province.
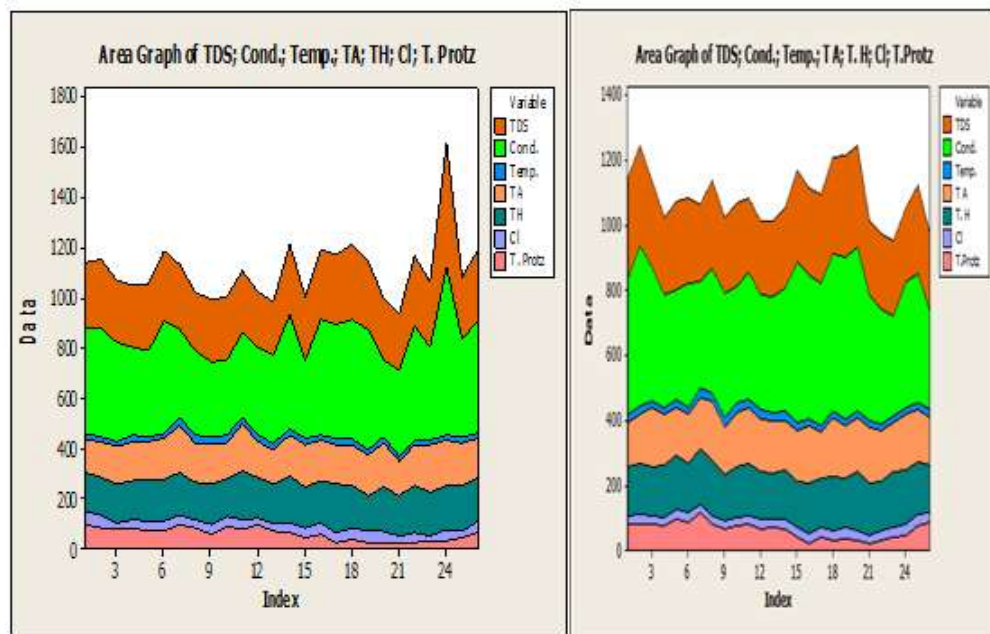

Meligue

Shobra-bass

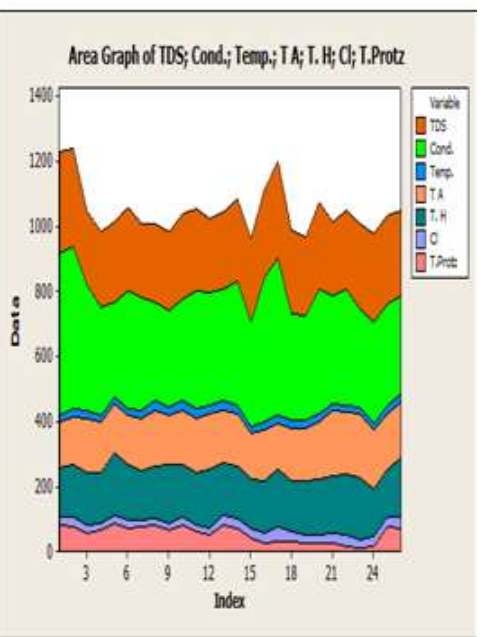

El-Dalaton

Fig. (2). Time series graph of different parameters in three water treatment works in El-Menofeyia Province, Egypt. 
Comparison between different water-treatment works in El-Menofeyia province, Egypt مقارنة بين محطات مختلفة لمعالجة مياه الثرب فى محافظة المنوفيــة بمصر.

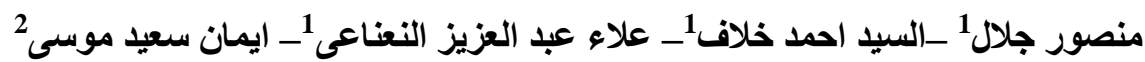

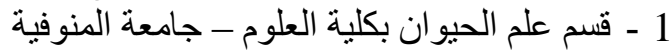

2 - الهيئة العامة لمعالجة المياه بشبين الكوم

\section{المستخلص}

أجريت هذه الدر اسة للمقارنة بين الخواص الطبيعية و الكيميائية و الحيوية للماء الخام الداخل و المعالج لثلاث

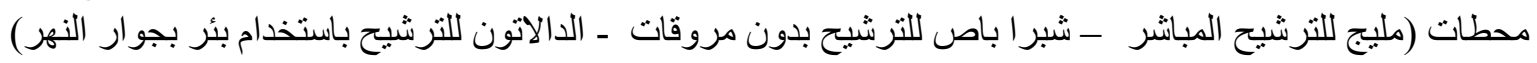

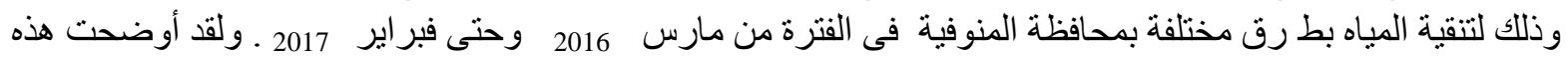

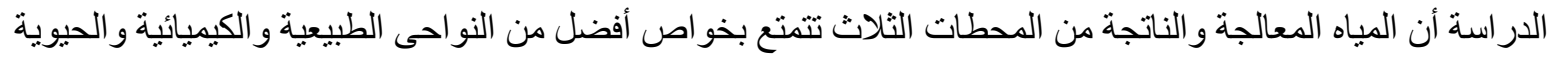

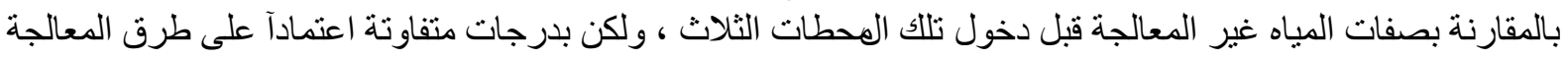

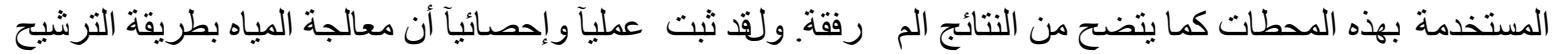

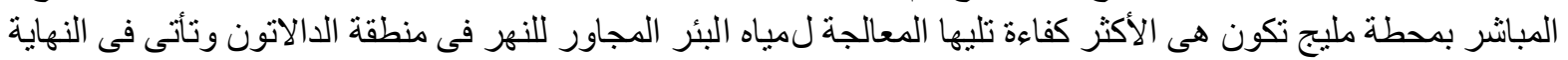

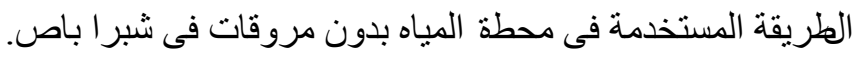

